\title{
Association of gestational diabetes and hypertensive disorders among pregnant
}

\section{women}

\author{
Sununta Youngwanichsetha* \\ Assistant Professor, Department of Obstetric-Gynecological Nursing and Midwifery, Prince of Songkla \\ University Hat Yai, Songkhla, Thailand
}

Received: 22 February, 2020

Accepted: 11 March, 2020

Published: 12 March, 2020

*Corresponding author: Sununta Youngwanichsetha, Assistant Professor, Department of Obstetric-Gynecological Nursing and Midwifery, Prince of Songkla University Hat Yai, Songkhla, Thailand, Email: sununta.y@psu.ac.th; sununta.y@gmail.com https://www.peertechz.com

Check for updates
Gestational diabetes and hypertensive disorders are common pregnancy complications among pregnant women worldwide because it shares metabolic and cardiovascular risk factors. Pregnant women with gestational diabetes are known to have insulin resistance pre-pregnancy and during pregnancy. Typically, they were diagnosed between 24 and 28 week of gestation using glucose tolerance test. Elevated of postprandial blood glucose more than $120 \mathrm{mg} / \mathrm{dL}$ or fasting blood glucose more than $95 \mathrm{mg} / \mathrm{dL}$ is considered poor glycemic control leading to pregnancy complications, particularly hypertensive disorders. The purpose of this review is to examine the association of gestational diabetes and hypertensive disorders among pregnant women and its outcomes. Inclusion criteria for recruited studied paper is the study of association of gestational diabetes and hypertensive disorders among pregnant women published within 5 year, 2016-2020. Exclusion criteria are 1) The study of association of pre-gestational diabetes, type 1 and type 2 diabetes and hypertensive disorders, 2) It is not printed in English.

There are four categories of hypertensive disorders in pregnancy: 1) Gestational hypertension, 2) Preeclampsiaeclampsia, 3) Preeclampsia superimposed chronic hypertension, and 4) Chronic hypertension. It can be classified into two groups of manifestation: Before 20week of gestation and after 20week of gestation. Pregnant women are usually diagnosed of chronic hypertension before 20week of gestation. Another groups developed hypertension after 20 week of gestation. Gestational hypertension is diagnosed when pregnant women develop hypertension, blood presser of $140 / 90 \mathrm{mmHg}$ or over after 20 week of gestation and without proteinuria. It is also named as transient hypertension of pregnancy. Elevated blood pressure and present of proteinuria are considered preeclampsia without severe features or with severe features.

Pregnant women with gestational diabetes who developed preeclampsia-eclampsia are overweight or obese, usually they were diagnosed after 24-28 week of gestation because of occurring peak of insulin resistance and endothelial dysfunction. Placental hormones act against insulin action in order to preserve blood glucose for developing fetus. In addition, prior insulin resistance due to oxidative stress leads to hyperinsulinemia and beta-cell dysfunction. Prolonged hyperglycemia, insulin resistance, and dyslipidemia also affect endothelial function leading to atherosclerosis, thickening and stiffness of vascular, vasoconstriction and its related complications.

Gestational diabetes and hypertensive disorders affect pregnancy outcomes including preterm labor and birth, macrosomia, maternal death, and perinatal death. Maternal gestational diabetes and hypertensive disorders are associated with large for gestational age fetus and macrosomia. Stillbirth rates in pregnant women with hypertensive disorders is $\mathbf{2 1 . 9}$ per1,00o birth. In addition, women with a history of gestational diabetes and hypertensive disorders are at risk for development of chronic hypertension later in their lives.

Primary prevention by raising awareness of healthier dietary pattern and doing regular exercise before conception and during the first half of pregnancy would be suggested for all pregnant women. The moderate intensity of prenatal exercise including brisk walking, water aerobics, stationary cycling, 
resistance training can prevent the development of gestational diabetes and hypertensive disorders among pregnant women. Early detection and management of gestational diabetes and hypertensive disorders in pregnancy would be helpful to delay development maternal and newborn complications. Lastly, modification of healthy behaviors is recommended for women with a history of gestational diabetes and hypertensive disorders in order to improve metabolic imbalance and cardiovascular pathogenesis. As a result, maternal and newborn complications will be decreased [1-10].

\section{References}

1. de Boer IH, Bangalore S, Benetos A, Davis AM, Michos ED, et al. (2017) Diabetes and hypertension: A position statement by the American Diabetes Association. Diabetes Care 40: 1273-1284. Link: http://bit.ly/33bknAl

2. Davenport $\mathrm{MH}$ (2018) Prenatal exercise for the prevention of gestational diabetes mellitus and hypertensive disorders of pregnancy: A systematic review and meta-analysis. $\mathrm{Br} \mathrm{J}$ Sports Med 52: 1367-1375. Link: http://bit.ly/38BE6KM

3. Gu Y, Lu J, Li W, Liu H, Wang L, et al. (2019) Joint associations of maternal gestational diabetes and hypertensive disorders of pregnancy with overweight in offspring. Front Endocrinol 10: Link: http://bit.ly/3aMnmCc

4. Haug EB, Horn J, Markovitz AR, Fraser A, Klykken B, et al. (2019) Association of conventional cardiovascular risk factors with cardiovascular disease after hypertensive disorders of pregnancy. JAMA 4: 628-635. Link: http://bit.ly/2Q3Qf4T

5. LJ L, Aris IM, Su LL, Chong YS, Wong TY, et al. (2018) Effect of gestational diabetes and hypertensive disorders of pregnancy on postpartum cardiometabolic risk. Endocr Connect 7: 433-442. Link: http://bit.ly/339kXP7

6. Moe K, Sugulle M, Dechend R, Staff AC (2019) Risk prediction of materna cardiovascular disease one year after hypertensive pregnancy complications or gestational diabetes mellitus. Eur J Prev Cardiol. Link: http://bit.ly/2VYL2iu

7. Timpka S, Markovitz A, Schyman T, Mogren I, Fraser A, et al. (2018) Midlife development of type 2 diabetes and hypertension in women by history of hypertensive disorders of pregnancy. Cardiovasc Diabetol 17: 124. Link: http://bit.ly/2TGbITD

8. Wang L, Leng J, Liu H, Zhang S, Wang J, et al. (2017) Association between hypertensive disorders of pregnancy and the risk of postpartum hypertension: A cohort study in women with gestational diabetes. Journal of Human Hypertension 31: 725-730. Link: http://bit.ly/2TDUmql

9. Xiong T, Mu Y, Liang J, Zhu J, Li X, et al. (2018) Hypertensive disorders in pregnancy and stillbirth rates: a facility-based study in China. Bull World Health Organ 96: 531-539. Link: http://bit.ly/2IECfug

10. Zhang S, Wang L, Leng J, Liu H, Li W, Zhang T, et al. (2017) Hypertensive disorders of pregnancy in women with gestational diabetes mellitus on overweight status of their children. Journal of Human Hypertension 31: 731736. Link: http://bit.ly/2TVD5Yz

\section{Discover a bigger Impact and Visibility of your article publication with} Peertechz Publications

Highlights

* Signatory publisher of ORCID

* Signatory Publisher of DORA (San Francisco Declaration on Research Assessment)

* Articles archived in worlds' renowned service providers such as Portico, CNKI, AGRIS, TDNet, Base (Bielefeld University Library), CrossRef, Scilit, J-Gate etc.

* Journals indexed in ICMJE, SHERPA/ROMEO, Google Scholar etc.

* OAI-PMH (Open Archives Initiative Protocol for Metadata Harvesting)

* Dedicated Editorial Board for every journal

* Accurate and rapid peer-review process

* Increased citations of published articles through promotions

* Reduced timeline for article publication

Submit your articles and experience a new surge in publication services (https://www.peertechz.com/submission).

Peertechz journals wishes everlasting success in your every endeavours.

Copyright: $\odot 2020$ Youngwanichsetha S. This is an open-access article distributed under the terms of the Creative Commons Attribution License, which permits unrestricted use, distribution, and reproduction in any medium, provided the original author and source are credited. 